\title{
MUSICALITY IN POLITICAL SERMONS OF NAHJ AL-BALAGHA LITERARY REVIEW OF TECHNICAL IMAGES IN THE PRESENCE OF IMAM ALI (PEACE BE UPON HIM)
}

\author{
Mohammad Saleh Sharif Askari, \\ Kharazmi University, Tehran, Iran \\ *Hamed Fashi \\ Kharazmi University, Tehran, Iran \\ *Corresponding Author
}

\begin{abstract}
Music forms an important part of influence on the audience and plays an important role in attracting intellects and minds. Rhetoric is one of the texts most in need of applying the potential of expression in order to influence the audience, because the artistic sermon (rhetoric) relies on absorption and persuasion; among them, political sermons are most in need of using emotional stimuli, so that the category of influence and persuasion can be realized and the audience acknowledges and believes in the thought that theorator (author) claim. Accordingly, the current research studies the quantity and quality of the use of music in the political sermons of Nahj al-Balagha, focusing on technical images based on descriptiveanalytic method. The most important result of this study is that Imam Ali (as) has used visual images with the potential of music and uses two types of verbal and spiritual music, thus has realized making the peak of beauty, pictorial, and influential. The fact that verbal music is diverse in Nahj al-Balagha's political sermons and involves a variety of rhymes, pun and replication, but spiritual music is merely limited in implication and does not include confrontation and marriage.
\end{abstract}

KEYWORDS: IMAM ALI (PEACE UPON HIM), TECHNICAL IMAGE, RHYTM, MUSIC, NAHJ ALBALAGH

\section{Introduction}

The human soul has a fond with the discipline and harmony of the phenomena, and it is elusive from the uncertainty and unpredictability of affairs (things). Therefore, if a writer or a speaker (orator) wants his speech to affect such a soul, he/she must adhere to the principle of creating the rhythm through the use of the verbal vocal (Henon, 2012, 113), because the voices in relation to hearing sense benefits from the viewpoint position for view (eyes) (Al-Jorjani, 2006, 412). The song of vocabulary (words) requires a kind of harmony and order, so that attractive music appeals to the audience, and meanwhile the rhythm of the word is the element of creator of musical coherence (al-Shawi, 2007, 164).The rhythm emanates from the structure of words, and not only isn't considered as a collection of repetitive voices, but also to represent meaning in the direction of continuous communication between the speaker and the audience and the subject (Sultan, 1986, 23 \& Alfaham, 2012, 212). Thus, music has such an effective effect on poetry of prose text that it can be compared with the influence of other poetic elements. On the other hand, from the old days, this is a well-known saying that Arab arranges the words and pays attention to their hidden meaning, "because the words like the Tar (string instrument) have a pleasing sound" (Ibn al-Fitr, 1939, $1 / 150)$.

Therefore, music plays an important role in creating a technical and impactful image on the audience, which consists of several elements: "the expenditure of letters, attributes and movements, and the sequence of their distribution in a certain structure, as well as consistency of sentences and expressions. In the clearer sense, the rhythm of the letters forms the rhythm of the words, and with the entry of the words in the sentences, the phrases and, finally, the overall rhythm of the words is formed" (al-Ragheb, 2001, 54 and 53). Accordingly, two types of verbal imagery music, including repetition, pun and rhyme, and spiritual imagery music including marriage, implication, and confrontation will be discussed (Henon, 2012, 115).

For the sermon, the ancients have believed that the sermon is a literature that its task is persuading the audience in a particular matter (Aristotle, 1979: 9). They also believe in the existence of the science of 


\section{MUSICALITY IN POLITICAL SERMONS OF NAHJ AL-BALAGHA LITERARY REVIEW OF TECHNICAL IMAGES IN THE PRESENCE OF IMAM ALI (PEACE BE UPON HIM)}

rhetoric, and in its definition have said: "A set of rules that familiarizes a person with verbal influences and good-faith persuasion by addressing the audience" (Abu Sohra, 1943, 1).

In order to realize this effect and persuasion, the rhetoric should be fiction and rhetoric, and therefore this literature) is like poetry, with the difference that the rhetoric, in contrast to poetry, in its general sense, is not poetry but is prose (Al-Ayatiq, 1972, 218). Therefore, it has been said: "Despite the difference in form, the sermon (oration, lecture) is considered to be the closest literary technique to poetry because it is based on the motive of emotion and feeling and the fertileness of the imagination and fantasy" (Alfalah, nd, 181). Sahib al-Sana'atin also considered the sermon (oration) as one of the types of poetry and has said: "The poem (poetic words)has three types: epistle, sermon, and poetry. All these types require a good writing and good combination (al-Askari, 1902, 120).

In Islamic times, due to the presence of a wide range of factors and needs, such as intellectual and political conflicts, the rhetoric (sermon) grew to a great extent, because during this period, apart from the speech (sermon), there was no other means for communicating with the audience's thought, and language more efficiently, to persuade the listeners and to insist on their argument and reason (Al-Fakhori, 1986, 335, 336) and the political sermon meant words "the orator express in the council or general meetings for the management of government affairs" (Sheikh, 1926, 2/169), thus the political sermon (speech) includes all the sermons which within the framework of the formation of the government or expansion of its influence is expressed, namely, when there is a confrontation between Muslims and non-Muslims, as in the its subset, there is sermon (speech) related to ongoing conflicts and clashes over the caliphate and the government among the Islamic community (Al-Amari, 2002, 50), it thus becomes clear that the principle of influence and persuasion in political speeches (sermon) is most important in comparison with other types of speeches.

\section{Statement of the problem}

The sermons of Amir al-Mu'minin Ali (Peace upon him), which is a valuable treasure of different education, in addition to mentioning the behaviors of the supreme, include various forms of rhetoric and prevailing forms of expression and exquisite, as well as the power of interpretation, rhetoric and verbal beauty, richness of meaning, and the harmonious structure of the sentence, distinguishes the aforementioned sermons from the others (Dakhil, $2001 \mathrm{~m}$ : 6). So this research seeks to answer two questions:: 1. Does Imam Ali (Peace be upon him) as a person who considers his speech below the creator and beyond the creature, uses music in rhetorical images of his rhetorics? 2. What are the different types of music used by Majesty?

\section{Research background}

Many books have been published in the form of books, theses and essays around NahjolBalaghah. Of these, most of the works are devoted to the religious, ethical, political, cultural and thematic aspects of the titles and compared to such subjects, a small amount of works are devoted to literary aspects of Amir's words, of which the most important ones are the following: the book "rhyming effects in Nahj al-Balagha "by Mohammad Khaghani; the book "Landmarksin literature of Nahj al-Balagha " written by Khalil Bastan; the book "Al The aesthetic levels in theNahj al-Balagha" by Noofal Abu Raghif; the book "eloquence approach in the Nahj al-Balagha "by Abbas Ali Faham; as well as articles such as "musical characteristics of rhyme in Nahj-al-Balagha "by Nematollah Behraghamand "the literary scene in the speeches (sermons) of theNahj-al-Balagha "written by RouhollahNasiri and HasanJalali, as well as student theses, such as "the methods of innovation in the Nahj-al-Balagha", by the efforts of Khalid KazemHamidi, which was defended at the University of Kufa in 2011. But itshould be said that in focusing on verbal and spiritual imagery music, with a special look at the technical images used in political sermons of Nahj-alBalagh, the current research in the past has not been conducted.

\section{Necessity of research}

The study of rhetoric used in Amir's words can be considered as one of the most important tasks of the literary class of an Islamic society therefore, it is not pleasant to admit the hidden aspects of the Nahj al- 


\section{MUSICALITY IN POLITICAL SERMONS OF NAHJ AL-BALAGHA LITERARY REVIEW OF TECHNICAL IMAGES IN THE PRESENCE OF IMAM ALI (PEACE BE UPON HIM)}

Balagh's rhetorical aspects, including its musical dimension, that is why this research focusing on the technical images of Nahj-al-Balagha's political lectures (sermons), has tried to clarify the extent of utilization of Imam Ali (Peace be upon you) from the verbal and spiritual musical capacities and the degree to which the expressive images intertwined with it in the Word of him (majesty).

\section{Discussion}

\section{First: verbal imagery music Rhyme}

From the perspective of terminology, the rhyme means the sense of solidity and righteousness, and the resemblance of some to the other, and also refers to the rhyming words" (Ibn-Manzoor, nd, Article s j a), as the term "pigeon coo" is used when "the pigeon repeats its voice in a uniform way, and also the same meaning is used to moan the camel" (Al-Zamakhshari, 1998: Article C). In the application of the term, the rhyme means that "intervals in the prose word are similar in one letter" (ibn al-Athir, 1939: 1/193). In fact the rhyme in the prose likes rime (rhyme) in poetry (Matloob, 1983, 1/144).

In the general categorization, there are three types for rhyme hence the co-ordination of the intervals is "either in letter or in weight, or in both of them. Accordingly, if the intervals are unified in the last letters and the weight, the rhyme is parallel rhyme such as the words of the Almighty God: (Fiha sororon marfoa va akvabon mozo'a) There are beautiful, lofty and tall beds, The Overwhelming, 13 and 14); If the intervals are the same in the last letters but their weight be different, the rhyme is reciprocal (Mutarraf) rhyme such as the words of the Almighty God, (Ma lakom la tarjoona lal hevgharan va ghad khalaghakoma tavalan) what is it to you that you do not give glory to the Lord while he has made you step by step - from the spit to the adult man (Noah., 13, and 14); if the intervals are the same in the weight but differentin letters, then this is called a balanced rhyme, as in this verse: (Va namaregho masfoofa va zarabio mabsoosa) Regular pillows and Fine and widespread carpets (The Overwhelming, 15 and 16) (Al-alawi, $1333 \mathrm{AH}: 3 / 18$ and 19).

Considering the use of rhyme in the Word of God, it should be acknowledged that the rhyme is "literary and natural sing" (Mubarak, 2010: 1/75), which was used as a visual element in Arabic, in the Islamic era, because of the presence in the text of the Quran and Hadiths of the Prophet were found to have been applied twice. Of course, this point should not be ignored that the sermon (lecture) is based on the auditory sense, and therefore the speaker needs some of the influential elements of hearing that are reflected in the rhyme, and thus, those language capacities that can coordinate the audience with the implicit meanings and the speaker's thoughts is in tune with the speech (words). It can be said that because of its effective auditory elements, which can be repeated in a regular or semi-regular manner, the rhyme can establish a connecting and aesthetic bridge between the two sides of the speech (sermon), namely, the orator and the audience (alHamidiyah, 2011: 49). Based on what wassaid, let's look at the various types of rhyme in the technical pictures of Nahj-al-balaqh.

\section{Reciprocal (Mutarraf) rhyme}

As stated above, the Mutarraf rhyme means that the two words are identical in the last letters, but they do not have the weight of unity and in the political sermons of Imam Ali (Peace be upon him), one can see examples of this rhyme, including:

(Telka shghsheghaton hadarat somma gharrat) "It was a burning flame that burned and then drooped" (Sermon / 3).

In this sentence between the two terms (Hederat, Qerat), we are witnessing a reciprocal (Mutarraf) rhyme because the words in the final letter are identical, that is an "intense audio, or according to the words of the later scholars, is an explosive sound" (al-Shawi, 2007: 173), and for this reason, the created music can express the intensity of the grief and inner turmoil of Imam Ali (Peace Be Upon Him).

(Nahno ahlo-al-beyte menha be menja va lasana fiha bedoa, somma yofarrejoha allaho ankom ka-tafrije aladim) We (Ahl al-Bayt) are safe from those tribulations and we do not call the people, then God will destroy the sedition of the Umayyad as the skin of flesh "(Sermon / 93). 


\section{MUSICALITY IN POLITICAL SERMONS OF NAHJ AL-BALAGHA LITERARY REVIEW OF TECHNICAL IMAGES IN THE PRESENCE OF IMAM ALI (PEACE BE UPON HIM)}

In this phrase, the two words "Menj'a and Daa'a)" are identical in the final letter but they are not identical in weight. Of course, it should also be pointed out that the use of reciprocal (Mutarrat) rhyme in the technical pictures of the political speeches of Imam Ali (as) is very rare and that's why we end up with these two examples, and we will deal with other types of rhyme.

\section{Balanced rhyme}

The balanced rhyme means that the two words are the same in weight but in the letter are different from each other. This type rhyme compared to reciprocal (Mutarraf) has a greater presence in the political sermons of Nahj-al-Balaghh, among which examples are the following: (Aimo allaho latajeddonna baniommaya lakom arbaba soo'e ba'adi, ka-al-nnabe al-zorose ta'azemo befiha va takhbeto be-yadeha, va tazebno berejolaga, va tamanna'o darraha, la yazaloon bekom hatta la yatrekoo menkom ella nafe'an lahom ao ghaira zarra behem) I swear to God that after the Umayyad there will be evil rulers, they will always deal with you like a camel that knocks, kicks and bites and does not refuse to milk, and will not leave you anybody except that have a benefit or mischief for them "(ibid).

In the aforementioned phrase, there is a total harmony among the words "Ta'azam, Thakhbat andTazban". This has led to a combination of meaning and music that is the product of the weighted harmony of these three words, without their final letters being the same. In the following sentence, there is a balanced rhyme between "Ghabsto, Basat'tom/Naze'atkom and Jazebatomoha": (Ghabazto kaffi fa-basatomoha, va naza'atkom yadi fa-jazabtomoha) I closed my hands but you insistedto openthem, I refrained from lying up for allegiance, and you pulled it out (sermon/137).

The same type of rhyme in the following words between the two terms (haram, halal) also becomes apparent, with the difference that the semantic contradictionhas doubled the beauty of the relationship between the vocabularies: (Ghad sara haramoha enda aghvamen be-manzelahi al-sedr-al-makhzoode va halaloha ba'eedan ghaira mojooden) The world's forbidden became like a thornless cedar tree and world's lawful (Halal) became difficult and impossible to reach in a group "(Sermon / 105).

A balanced rhyme is also found in the two words of "al-Sayyil al-Ta'ir" where the Prophet (PBUH) says:(Yanhadero anni al-sailon, va la yargha elayya al-tairon)The public floods are flowing from my mountains and the birds can't reach the high point of my flight" (sermon / 3).

The existing unilateral relationship between the two terms, of "Al-Hassina and Al-Waithiqa", indicates the existence of a balanced rhyme between the two: (Fa-enna al-jaada babon men abvabe-al-jannah, fataha allaho le-khasehi aoliaehi va hova lebaso al-taghva, va dero allahe al-hasinao va jantohal vasighagho) The jihad is a door from the doors of Paradise, which God has opened for his particular people, as well as the Jihad is piety dress and stronghold, and the imperturbable shield of God" (Sermon / 27).

As a result, the balanced rhyme, in comparison with the reciprocal rhyme (Mutarraf), has more application and role in the technical pictures of Imam Ali's (PBUH) political sermons, thus becoming one of the musical indicators that require technical interpretation, especially since this type of rhyme is present in Nahj al-Balagha as the secondary creation of meaning, which is itself the result of the poet of Imam Ali (PBUH)" (al-Faham, 2014: 243).

\section{Parallel rhyme}

Parallel rhyme means that the two words are identical both in weight and in the letter. This type has a great presence in the political sermons of Nahj-al-Balagha, among which examples are the following: Kal jabale la taharrakoho al-ghavasefo $\mathrm{v}$ all toziloho al-avasefo, lam yakon le-ahaden fiya mahmazon va la leghaelen fiya maghmazon "Like a mountain that the gusts did not move, and the storms did not leave it, nobody could find fault in me or get an excuse to slander and defile (sermon/37). In the aforementioned phrase, there is a total harmony between the words of "Al-ghavasef and Al-avasef)", also, between the "Mahmaz and Maghmaz), the balanced rhyme has been used in a single technical image.Other examples of this type of rhyme can be referred two words of "Elnaii, Elbaki" in the following words: (Va allaheh la akono ka-mostame'e al-dame, yasmao al-nhaeea va yazoro al-bakeea, somma la 


\section{MUSICALITY IN POLITICAL SERMONS OF NAHJ AL-BALAGHA LITERARY REVIEW OF TECHNICAL IMAGES IN THE PRESENCE OF IMAM ALI (PEACE BE UPON HIM)}

ya'etabero). By God, I am not the one to hear the cry of voice, the head and chest for the deceased, and hear the call of the angel to death and do not learn lesson (sermon/148), and also the two terms of (Jaza'a, amia'a) in the following statement, are another proof for a parallel rhyme: Tafeghto artaya baina an asoola be-yaden jaza'a ao asbera ala tekhia amia'a) I was wondering if I could stand alone with my hand to get my right, or wait in this dark, suffocativeenvironment (sermon/3).

Other examples of parallel rhyme can be found in the musical relationship between the two words "Qaza, Shoja" in the following words: (Fa saberto va fi-al ayne ghazi va fi al-halghe shajjan aro torathi naheban) I waited patiently, as if the thorn had remained in the throat in the eyes and the bones, and I saw with my eyes that they would loot my legacy (ibid).

Also, between "Makhzood and Majood" in the sermon ahead: (Ghad sara haromoha enda aghvamen bemanzelahi al-sedre al-makhzood va halaloha baeedan ghairo mojood) The world's forbidden became like a thornlesscedar tree and world's lawful (Halal) became difficult and impossible to reach in a group "(Sermon / 105). And also between the "Da'amah and Ma'alemah), which is coincided with the balanced rhyme between "darasatsoboloh and afatshorokoh": (Khozel al-imano fa'anhart da'aemoho, va tankarrat moa'lemoho va darasat soboloho va afat shorokoho) Faith is helpless, its columns are devastated, its signs are anonymous, and its ways are old and forgotten"(Sermon / 2).

In this way, we find that among the different types of rhyme, the parallel rhyme has the most presence in the political sermon of Nahj al-Balagha, and Amir al-Mu'minin (PBUH) uses it consistently with the meaning of the aim. In other words, Imam Ali (PBUH) did not seek merely entertainment in the context of the use of this rhyme.

In addition, it seems that this type of rhyme will be more durable in memory due to both equipoise and unison characteristics, therefore, it can be said that the majesty (Ali PBUH) incorporates its meanings with the maximum use of this type of music. The choice has been purposeful and cleverly, in fact, he involves the music into the meaning of the meaning. and in this way it is emphasized that, in order to avoid of weakness and vulgarity in words (sermon), the word should follow meaning, not that which (meaning) is captive and function of the word because, if the meaning follow the word, we will encounter a phrase that has been decorated with a false and innocuous appearance, such as putting a wooden sword in the heart of a golden sword "(Ibn al-athir, 1939: 196/197).

It is clear from what has been mentioned that the rhyme in the words of Imam Ali (PBUH) is a technical necessity, which is rooted in nature, which is used by literary as if both have the same root, and as a result, prose as a poetry and melodious, with images that are in line with meaning are presented to the audience in such a way that they are received in goodness. The music used "is one of the main elements of the sentence and, while being complementary to the phonetic, is also a semantic complement, so that as fully and fitting with phrase content, highlight their presence as an influential element of the sentence "(Behragham, 2014: 107).

\section{Pun}

Gender (Jens) in the word means a kind of thing, like humans and birds, and the limits of syntax and verbs, and all other things". The same is the root of the two terms, al-Mujansah and al-Tajnis, and it is said: "hazayojaneshaza", in the meanwhile," means the similarity of these two things" (IbnManzoor, n.d. Material of J N S), they also say: "Keyfayoa'aneska man la yojaneska" (Al Zamakhshari, 1998, 97) means that how can someone who is not from your gender can get herself with you? It is also quoted from Khalil that he has taken "HazayojansHaza" (This harmonizes this) in the sense of "HazayashakalHaza" (This forms this) (Al-Madani, 1969: 1/97).

But in the term, pun is to mean two or more words are the same in words, but different in meaning (Ibn alHitar, 1939, 1/246). However, in some cases the words may not be identical, but have some verbal similarities that can be treated as pun. Alawi considers the pun in the sense that: "The two terms are equal in an aspect of several aspects, but the meanings of the two are different" (al-Alawi, 1333 AH: 2/356). In 


\section{MUSICALITY IN POLITICAL SERMONS OF NAHJ AL-BALAGHA LITERARY REVIEW OF TECHNICAL IMAGES IN THE PRESENCE OF IMAM ALI (PEACE BE UPON HIM)}

this regard, it may be said that the commonality in the word and dispute in the meaning is the pillar and the mainstay of the pun.

This point should also be added since commonality in words means commonality to all or some of the letters,inevitably, a kind of audio unison will be created in the word. On the basis of this, it can be said that the unilateral and rhythmic commonality are the pillars of the pun.Perhaps because of the fact that AlAzhar al-Zanad regards pun as "equality and unifyof two or more words in the shaping sounds and their differences in the meaning of their dealings" (al-Zanad, 1992: 153).

There are many types of puns that can be categorized in two sets of perfect and imperfect pun. Of course, this research does not seek to provide a definition of all kinds of pun, and the effort will only be aimed at examining the types of pun contained in the technical pictures of the Nahj-e Balagha's political sermons and presenting samples from each one. It should be noted that in this research, none of the examples of perfect pun has been obtained in the technical pictures of Imam Ali's (PBHU) political speeches (sermons), therefore the study in this section focuses on the imperfect pun.

\section{Derivation pun}

Derivation pun means that "the two words have the same root, which is also called the absolute pun" (alAlawi, $1333 \mathrm{~A}: 2 / 360)$. In this way, we find that the criterion of action in this type of pun is the cognate of two or more words, even if the number of letters is different. Imam Ali (PBUH) has used this kind of pun in political speeches (sermons), among which one can mention the following: (Fa-kharajoo yajorrona hormaha rasoole allah-sallalaho alayhe va alehei-kama tojarro al-omaho enda sheraeha motavejehina beha ela-al-basra, fa-habasa nesa'a homa fi boyoto homa va abraza habisa rasoole allah-sallalaho alayhe va alehei) They rebelled against me, and - Aisha - took the wife of the Prophet (PBUH) to God as a slave dealer who was moving to Basra, and while keeping his wives behind the curtain, introduced the hermit of the shrine of the Prophet (PBUH) before the eyes of all "(Sermon / 172).

In this phrase between the words (Yajron, Tajer) and (Habsa, Habis), we see the derivation pun. In the following sentence, there is also the same type of pun between two terms (Meth and Yomath): (Allahomma mes gholobahom kama dmaso al-malho filma'a) Oh Lord!Dissolvetheir hearts, as salt is dissolved in water" (Sermon / 25). Other examples of derivation pun in the vocabulary of political lectures (sermons) of Nahj-al-Balaghainclude the following (Ghab and Eghtab): (Hatta takoona nosraho ahadekom men ahadekom ka-nosrahi al-abde men sayyedehi eza shahedaho ataaho va eza ghaba aghtabaho) In such a way that you can help one another, like helping a slave from his master, who is obedient in the presence of the master and mumble in his absence "(Sermon / 98) (Sermon / 98).

And between (al-Mostame'e and Yasma'a)(Vallahe la akoono kamostame al-damme, yasmao al-naeeia, va yahzoro al-bakia somma la ya'tabero) By God, I am not the one to hear the cry of voice, the head and chest for the deceased, and hear the call of the angel to death and do not learn lesson (sermon/148). And also between (al-Sahib and Mostashaba) (Va la yazalo bal'ohom ankom hatta la yakoona entesaro ahadekom menhom alla ka-al-entesare al-abde men rabbehi va al-sahebe men mostashebehi). The disaster of the children of the Omayyad will remain upon you as long as you seek help from them, as if you are willing to seek servants from your own municipality or help you to surrender from your owner "(Sermon / 93). As the derivation relationship (Tadakaktom, Tadaka) occurs in the following sentence: (Fa tadako ala tadaka alebele al-hime verdeha va ghad arsalaha raeeiha va kholeat masaniha) As you were thirsty camels that were thrown down and flooded to your waterfall, you attacked me and gathered around me "(Sermon / 229).

And between (Rawa, Truwa) in the following words: (Faghero ala mazalle va ta'khire mahallehi ao ravo alsoyofa men al-dema'e tarvoo men al-ma'e) Or sit down with their humility and ignominy, or shed their sword out of the blood, so that they will be watered "(sermon / 51). By God, I swear to you what you have done, until the situation of the Muslims is in order and not wronged by anyone except me "(Sermon / 74).

It is obvious that this type of pun brings rhythm to the texts of the lectures (sermons), and the musical rhythm of the vocabulary is very pleasant, because the derivation leads to the repetition of sound in the repetition of the letters (Henon, 2012: 130). The consequence is that the derivation pun in metaphorical 


\section{MUSICALITY IN POLITICAL SERMONS OF NAHJ AL-BALAGHA LITERARY REVIEW OF TECHNICAL IMAGES IN THE PRESENCE OF IMAM ALI (PEACE BE UPON HIM)}

images of to the Nahj-al-Balagha political speeches (sermons), and especially in those eloquent metaphorsthat similarity relationship has been established between verb and infinitive, is most widely used, and examples of proof of this finding are also mentioned.

\section{Similar (Mozare'e) pun}

"The term "Mozare'e" means the same thing (similar) and an object is therefore referred to as the Zar (similar) of another object, which is in appearance similar to another, and when the two are similar in something, the term is called Mozare'e. The "similar (Mozare'e) pun"means that the two words are completely identical and they differ only in one letter, which may be the difference among the initial and the middle, or the ending (Al-Alawi, $1333 \mathrm{AH}$ : 2/366 and 367). "If two words differ in various letters, this difference should not be more than one letter," says Qazvini. Then, if two different letters are convergent, such a pun will be called similar (Mozare'e) pun(Al-Qazvini, without date: 396 and 397). Accordingly, we will mention two examples of the similar (Mozare'e) pun in the sermons of the Nahj-al-Balagha (Ka-aljabale la toharreko al-ghvasefo va la toziloho al-avasefo, lam yakon le-ahaden feya mahmazon va la leghaelen faya maghmazon) "Like a mountain that the gusts did not move, and the storms did not leave it, nobody could find fault in me or get an excuse to slander and defile (sermon/37).

In this phrase, there is a similarity between the two terms (al-ghavasef and al-avasef), so that both the ghaf(ق)and ain(ع)both are expressed by throat; on the basis of this, there are also "similar (Mozare'e) pun" between the two words (Mahmaz and Maghmaz): the difference between the two words is merely in the second letter, and both $\mathrm{Ha}\left({ }^{\circ}\right)$ and Ghein $(\dot{\varepsilon})$ are expressed by throat that are convergent in the sound output (NK: Alfaham, 2012: 269).

In this research, with the exception of the two examples, there was no other evidence for the use of "similar (Mozare'e) pun" in the technical pictures of Imam Ali's (pbuh) political speeches (sermons).

\section{Lahegh Pun}

Definition of this pun is the same as "similar (Mozare'e) pun", but there is a slight difference between the two. This kind of pun is also created between two words with similar appearance, to be different only in a primitive, intermediate or final letter, but different letters do not have any convergence of voice with each other. This kind of punis also called Laheghpun (al-Alawi, $1333 \mathrm{AH}: 2 / 367)$. In the Lahegh pun, one of the two pillars of the word is different from the other, but this difference should not appear at the beginning or the middle or the end of the word, since the meaning is only their difference that it takes place in any form (Aljwini, 1985: 191).

Compared to its similar pun, "similar (Mozare'e) pun", the lahegh pun is more extensive in the technical images available in Nahj al-Balaghah's political speeches. Examples of this presence include the following: (Konto akhfazahom saotan va a'alahom faotan) "My voice was slower than ever, but in practice I was superior and pivotal"(Sermon/37).

In this phrase, the example of the two witness words are "Saotan and Faotan", because these two words are different in the initial letter, and these two letters are not convergent in the pronunciation, because "Sas(ص) is a gingival phonemeand fa (ف) is a dental and labial phoneme" (Al-Khooli, 1982: 184). In the following statement, it is also possible to obtain between the two words (Mamdood and Ma'adood) a lahegh (portmanteaux) pun: (Va sadaftomoha vallahe zellan mamdoodan eld alalen ma'adooden) I swear by God that the world in your hands is like a shadow that will soon approach its head "(Sermon / 105).

The two words are different in the second letter, and there is no convergence between the two, because $\operatorname{Mim}(\curvearrowright)$ isa nasal and labial letter, while ain ( $(\varepsilon)$, is afriction and pharyngeal letter (al-Khooli, 1982: 185).

In the following words, lahegh(portmanteaux) pun is also seen between (Rijal and Hijal): (Ya ashbaha alrejale va la rejala, holomo al-atfalle va ogholon rabate al-hejale) Oh, cursed pseudo-man, wisdom-less childish men, whose wisdom resembles the veiled bridegroom "(Sermon / 27). It is clear that the difference 


\section{MUSICALITY IN POLITICAL SERMONS OF NAHJ AL-BALAGHA LITERARY REVIEW OF TECHNICAL IMAGES IN THE PRESENCE OF IMAM ALI (PEACE BE UPON HIM)}

between the two words is in the first letter, with the explanation that the ra $(\jmath)$ is gingival and Jahri letter, but ha (حاء) is a pharyngealand hidden (mahmoos) and non-Jahriletter (Al-Khooli, 1982: 184 and 185).

Another example of this puncan be found in two words (aob, shaob), where Imam Ali (PBUH) says:

(Jofahon taghamon va abidon aghzamon, jome'o men kolle aoben va tollagheto men kolle shaob) "The Shamites are the coveted desires of the poor and the slaves of the poor, who are gathered from every corner and formulated from different groups" (Sermon / 238).

The difference between these two words lies in the two primitive letters, namely, Hamzah(s)and Shin (ش), it is sufficient to point out that "the Hamzah (๕)of the vowels but shin (ش) is consonant and silent letter" (Abbas, 1998: 47), and hence the relation between these two words is lahegh pun.

As the last instance of the lahegh pun, we look at the two terms (al-tavasof and al-tanasof) in the following statement:

(Fa-al-hagho aosao al-ashya'e fe-al-tavasofe va azighoha fe-al-tansofe) Right in the description, is the most widespread phenomenon, and when you practice, the arena is tightest "(Sermon / 216).

The difference between the two words is in the second letter, and since vav (g) is a vowel andlabialletter, but noon (ن) is a nasal and gingival letter (Al-Khooli, 1982: 184 and 185/Abbas, 1998: 47 and 50). Therefore, the difference is in divergent letters. Therefore, the pun between the two words is a kind of lahegh (portmanteaux). It thus becomes clear that the lahegh (portmanteaux) pun is a widespread and decisive part in the technical depiction of Nahj-al-Balagha's political speeches (sermons) to create a pleasant rhythm in the words.

\section{Imperfect pun}

The imperfect pun means that the words are different in terms of weight and composition in one letter (Ibn al-Athir, 1939: 1/255). In other words, in this type of pun, the main letters of one of these two words, is less than the other (Matloob, 1983: 2/107), which results in a difference in the number of main letters, whether at the beginning or the middle, or the ending, in words (Al-Taftazani, $1428 \mathrm{AH}: 459$ and 460), therefore, the additional letter either located in the initial, such as: (al-hal and al-mahal), or this addition occurs in the middle such as: (Jeddi and Jahdi) or at the end of one of the words like: (al-hava and al-havan), the first type is mardoof imperfect pun, the second type ismoktanefimperfect pun, and the third type isreciprocal(mutarraf) imperfect pun (Al Hashimi, 1999: 426).

In the following, we will highlight examples of imperfect pun in the technical depictions of Nahj-alBalagha's political speeches (sermons): (Faghero ala mazellen va takhiren mahalen ao ravoo al-soyoofa men al-dema'e tarvoo men al-dema'e) Or sit down with their humility and ignominy, or shed their sword out of the blood, so that they will be watered "(sermon / 51). Witness of example liesin two terms of (aldama, alma), because in the combination of the first word, the letter "dal" (د) is more than the second word, and as a result a part of the music of the word is formed by Mardoof imperfect pun. Among other examples of imperfect pun, the relation between the two terms (jazr and jazoor) as follows:"'Fa'enda zaleka tavaddo ghoraysho be-al-donya va ma fiha, lao yaroonani maghaman vahedan va lao ghadra jazre jazooren, leaghbale menhom ma atlobo al-yama ba'zaho fa-la yo'tonani) Quraysh likes to have what is in the world, to see me, once in a short moment, in the direction of the camel, to accept from me a certain part of what I want and do not give me today"(sermon / 93).As can be seen, the lettervav (و) was added to the middle of one of the two words -Jazoor- in the Moktanef imperfect pun.

In this research, only two examples were found for the imperfect pun, in which the contribution of each of the two imperfect pun (Mardoof and Moktanef) was an example; therefore, no examples were found for reciprocal (mutarraf) pun in the technical images of Nahj-al-Balagha'spolitical sermons.

\section{Moharraf Pun}




\section{MUSICALITY IN POLITICAL SERMONS OF NAHJ AL-BALAGHA LITERARY REVIEW OF TECHNICAL IMAGES IN THE PRESENCE OF IMAM ALI (PEACE BE UPON HIM)}

The Moharraf Pun means that "the letters in their composition are equal but unequal in weight" (ibn alathir, 1939: 1/253), meaning that "the number and type of letters in the words are the same but have a different in vow, such as: Al-Bord and Al-Bard "(al-Qazviny, without date: 395). Of course, we found only one example of this kind of pun in the technical pictures of Imam Ali's (pbuh) political remarks (sermons), which are mentioned: (Fa-enna al-jahada babon men abvabe al-janna, fataho allaho le-khassa aolya'ehi va hova lebaso al-taghva va dar'o allahe al-hasinahi va jonatoho al-vasigha) The jihad is a door from the doors of Paradise, which God has opened for his particular people, as well as the Jihad is piety dress and stronghold, and the imperturbable shield of God "(Sermon / 27). In this statement, the two words (Jannah, Jonnah) in the composition and the type of letters are the same but different in vow, with the explanation that the vow of the first letter is one of the two terms is fatheh( $6 \dot{0})$ and another is zammeh(o), and thus the Muharraf pun between the two words is manifested and the above words are matched with music.

\section{Musahhaf pun}

This pun appears in a state in which "the two sides are in identical letters but at different points" (alMadani, 1969: 1/180), as in the words of Allah Almighty who says: Hom yahsabona anna hom yohsenoon "They think they're doing good" (The cave/104)." It can be said that this pun means "the mention of two similar words, not in terms of words, but in terms of line, and hence also refers to the tajnis-al-khat (linear pun)" (al-Alawi, 1333 AH: 2/365). Within the framework of this research, only one sample of the Musahhaf pun was found: (Fa-ennaha-ayal khelafa-ka-anta asaran shahhat alayha nofooso ghamen va sakhat anha nofoso akharin) A curmudgeon group stuck to the seat of the caliphate and a group generously gave it "(Sermon / 162).

The pun relation between the two terms of (Shehat and sekhat) rooted in the Tashif, and if the points are deleted, both words will be identical in terms of the line. What happened in the second type of verbal music was a report from the study of the various type of pun in the technical depictions of Nahj-al-Balagha's political sermons. It was revealed that perfect pun was not involved in political sermons, and the majesty (Ali PBUH) merely used the musical ability of all kinds of non-perfect pun, and "the truth is that Imam Ali has had more meaning in his words than a musical word. And this type of music the aftermath of the meaning has been considered by Imam Ali (PBUH)"(Alfaham, 2012: 269).

\section{Repetition}

This means that one or more words are repeated for a reason (Al-Madani, 1969: 5/345), and is divided into two categories, a repetition of the word and meaning, such as that which is said to someone: Asra'aAsra'a; another type of repetition is obtained only in meaning, while the words are different from each other, as in this statement: Ate'eni and Ta'aseni(ibn al-'Athir, 1939: 15/15 and 158). Based on this, we address the repetition industry in the technical pictures of Imam Ali's (PBUH) political speeches (sermons). In this regard, it should be said that Imam Ali has used many repetition in order to establish meaning in the audience. Of the numerous it can be mentioned in the following examples: (Fa-enna al-shaze mena-al-nase lel sheitane kama an al-shaze men al-ghaname lel za'abe) Man is far removed and only belong to devil, as sheep is the only wolf's bait "(Sermon / 127).

In this phrase, word (al-shaz) is repeated from the point of view of the word and spirit in which the meaning is established in the mind of the audience, because in both cases the result of the transgression is destruction and ruin, which is accomplished either by the claws of the devil or by the wings of the wolves. In this way, the audience will be discouraged from transgression. Other examples of repetition in the words of the Imam include the following: Hom asaso al-din va emado al-yaghine elayhem yafeo al-ghali va behem yolhegho al-tali va lahom khazameso haghe al-velaya va fihem al-vasi'o va -al-valreso The Prophet's family is based on faith and pillars of certainty, the extremists have to return to them, and the settlers join them because the attributes of the right of the guardianship are devoted to them and the Prophet's will belongs to the Muslim caliphate and the legacy of the mission" (Sermon / 2).

In aforementioned statement, the repetition of the pronoun (Hom [they]) seeks the fixation of this meaning in the eyes of the audience that Ahl-e- Beyt (PBUT) are way of sacrifice and reward. Therefore, using the 


\section{MUSICALITY IN POLITICAL SERMONS OF NAHJ AL-BALAGHA LITERARY REVIEW OF TECHNICAL IMAGES IN THE PRESENCE OF IMAM ALI (PEACE BE UPON HIM)}

musical industry of repetition, Imam has made the abovementioned semantic representation. Vallahe masta'jala motajarredan lel-talabe be-dame othmana ella khafan men an yotalaba be-damehi I swear by God that Talha did not rebel against Othman's blood revenge except to fear that Othman's blood would be demanded from him "(sermon / 174). In this phrase, the word (al-dāmm) has been repeated, which can be linked to stabilize the murder of the third caliph.

In another case, we find that Imam Ali (PBUH) uses repetition to establish a permanent relation between a frequent word and its subsequent words, where he says:

Ala va enna akhofa al-fetne endi alaykom fentnaho bani ommaya fa-ennaha fetnaho amya'o mozlemaho ammat khottatoha Beware, the most terrible intrigue on you is, in my opinion, the sedition of the Omayyad, a seditious sedition that becomes dominant and inclusive"(Sermon / 93).

In the majority of Imam's words, sedition and Omayyad are related and the repetition of the term associated with it leads to the expression of this meaning in the minds of the audience, which sedition is the Omayyad and Omayyad is the same sedition. In some cases, Amir al-Mu'minin (PBUH) uses repetition to blame his contemporaries as much as possible, as well as his full expression of his pain and distress: Ya ashbaha-alrejal, holom-al-atfale va ogholo rabate al-hejal $\mathrm{O}$ cursed pseudo-man, wisdom-less childish men, whose wisdom resembles the veiled bridegroom "(Sermon / 27). In this word, the Imam blames the men of his time and expresses disgust with his companion with them, and these two meanings of the quality of the repetition of the word (Rijal), as well as the conjunction of the two words (Ashbah, la) with the termMokarrar (repeated), are perceived. In some cases, Imam Ali (PBUH) uses the repetitive pattern to remind one of the forgotten things:

Fa-aghbaltom elayya eghbala al-oze al-matafile ala aoladeha tagholona al-bayaha al-baya'a You brought me people, like new mothers who were racing towards their children, while you cried out allegiance, allegiance"(sermon / 137).

In this phrase, Imam uses a similitude imagination along with repetition style as a complementary element, and as a result of repeating the vocabulary (al-bayat) of the audience he begins to recall his former state and then explains it to him that this is a kind of taking confession from the audience. Regardless of the purpose of Amir-Mu'minin (PBUH) in the application of repetition style, it should be said that "this industry is one of the most used musical instruments of the Imam, and Imam has used this instrument to formulate the song of phrase so that the form is based on content" (al-Faham, 2012 m.: 246). New research also emphasizes that "the repetition due to the internal and external sonority of the composer is one of the most prominent phenomena of the sing poetry" (Abu Raghif, 2011: 65). It can be said that the characteristics of the style of Imam Ali (PBUH) in the situations of addressing (sermons), are the use of repetition to stabilize the meaning and influence the audience along with the use of synonyms and the choice of rhythmic vocabulary (Jordac, 2002: 30).

\section{Imagery spiritual music}

\section{Implication}

Implication (Tebagh) is derived from (Tabagho, Motabegha and Tebaghan) and meansequality and conformity of those two with each other (IbnManzoor, without date: T B Gh). In terms of terminology, implication means alignment, and contrast, and also is calledadequacy (Al-Madani, 1969, p. 2: 31), and in the words "the implication is to mention an object with its counterattack" (Al-Alawi, 1333 AH: 2/377). It thus becomes clear that the implication means the coming together of the two opposite meanings (alMadani, 1969: 2/31), as in the words of the Almighty God: Fal yazhekoo ghalilan va la yabko kasiran From here on, laugh less and cry more (The Repentance / 82), which are mutually contradictory. Another point is that contradiction may occur in words and meanings, or only in meaning.

In a general division, the implication is divided into two types: the appearance implication and hidden implication. The appearance implication is divided into two categories: Requirement and deprivation. In the 


\section{MUSICALITY IN POLITICAL SERMONS OF NAHJ AL-BALAGHA LITERARY REVIEW OF TECHNICAL IMAGES IN THE PRESENCE OF IMAM ALI (PEACE BE UPON HIM)}

case of requirement implication, the two words in the dictionary contain opposite meanings, such as the contradiction between the two terms (al-baeed, al-Qarib) (far and near) and (Abka and Azhak) (laughed and cried). The deprivation implication also means that a word has two positive and negative meanings (alZanad, 1992: 173 and 174), as in the words of Allah in the Holy Qur'an: Yastakhfoona men al-nase va la yastakhfoona mena allah They hide from people, they do not hide from God (Women/108). In fact, it can be said that the deprivation implication in the majority of cases is occurred on an action that has been used in a speech (words) in two positive and negative forms.

The second of implication is hidden. In this kind of "contrast between the explicit appearance of a word and the necessity of another word is established, as in the words of Allah Almighty: (Asheddao ala-al-koffare rohamo baynahom). They are strict for the disbelievers and are kind to each other. (The Victory / 29), with the explanation that the opposite of strict and severity is, of course, kindness and softness, but, in this verse, the word of mercy, which is of elements of softness, on the basis of its necessity, has become the contradiction of word strict and thus the hiddenimplication has been created(Al-Zanad, 1992: 174). Based on what was said we are going to examine the implication in the technical depictions of the Nahj alBalagha's political sermons.

\section{Appearance implication}

The appearance implication in two types of requirementand deprivationhas an extensive presence in the words of Imam Ali (PBUH), and we will mention some examples of it. The appearance implication in theNahj al-Balagha in some cases is between two names, as we see in the examples below. Including the relationship between the two terms (al-halal, al-haram) in the following words:" Ghad sara haramoha enda aghvamen be manzela al-sedre al-makhzoode va halaloha bayeedan ghaira maojooden The world's forbidden became like a thornless cedar tree and world's lawful (Halal) became difficult and impossible to reach in a group "(Sermon / 105). And between (al-doniya, al-akherat) (world and the hereafter):

Fa kanat moalejehi al-ghetale ahvano alayya men moalejahi al-eghabe va matato al-donya ahvno alyya men maotate al-akherahi "In that context, it was easier for me to fight than to be punished by God and losing the world is easier than leaving the hereafter "(Sermon / 54).

And among the words (al-hoda, al-zalalah, al-basirah, al-omi) in this speech of the Imam Ali (PBUH): Fa abdalana ba'da al-zalalehi bel hoda va a'atana al-basirao al-ama "God led us out of astray and guided us, and gave us insight instead of blindness" (Sermon / 216).

And it is possible that the appearance implication is established between two verses, as in the relationship that Imam has established between two terms of (yohion and amitto):

Yartaze'ona amma ghad fatamat va yohyona bed'aha ghad amitat They want to drink milk from the breast that is dead and they want to revitalize innovation (heresy), which has long been dead "(Sermon / 22).

And we see the same relationship between (Aghbazo and Absato): Ma hia ella al-koofaho aghbazoha va absatoha Kufa's only government remains in my hands "(Sermon / 25).

And also between the two verbs "Tahdi and Tazal) in the words ahead: -as-alooni ghabla an tafghedooni fa-vallazi nafsi be-yadehi la tas-alooni an shayen fima baynakom va bayna al-saehi va la an fa'ehen tahdi ma'ahon va tozellon ma'ahon Before you lose me, ask me, by God who my life is in his hands, you do not ask something of what is going between you to Day of Judgment rather than a group astray a or direct a hundred people(Sermon / 93).

Sometimes, Imam (PBUH) establishes appearance implication between two verbs inone sentence, such as what is seen between "Aghbel and Adber" in the following words:

Yaban abbasen ma yorido othmano ella an yajalani jamalan nazehan be-al-gharbe aghbel va adber Oh, Ibn Abbas, it is notonly that Othman wants to hurt me like a camel" (sermon/240). 


\section{MUSICALITY IN POLITICAL SERMONS OF NAHJ AL-BALAGHA LITERARY REVIEW OF TECHNICAL IMAGES IN THE PRESENCE OF IMAM ALI (PEACE BE UPON HIM)}

Occasionally, the appearance implication is appeared between two infinitives, examples for this type is presented. Likewise the relationshipamong the words (Ehia'a, Ematah, al-ejtema'a, al-Efteragh) in the phrase: (Ala man da'aa ela haza al-shoare fa-aghtoloho va lao kana tahta amamati hazehi, fa-ennama hokama al-hakamane le-yohiya ma ahia al-ghor'ano va yomita ma amata al-ghor'zno va ehya'oho alejtemao alayhe va amatatoho al-efteragho anho). Be aware! Whosoever calls people into a slogan of division, kill him even if he is under my turban. If the arbitration was handed over to them, it was only because they revived what the Qur'an revives and they kill what the Qur'an calls dead- to act in accordance with the Quran - the revival of the Qur'an is unity in its operation, and the Quran's passing is a separation from it" (Sermon / 127).

As well as two terms (Al-ejtema and Tafarrogh) in the following words: By (Vallahe yomito al-ghalba va yojlebo al-hamme men ejtemae ha'olae al-ghaome ala batelahem va tafarreghekom an haghghekom) God, this fact kills the hearts of man and causes grief that they - Damascenes- are united in their falsehood and you are dispersed in your own right "(Sermon / 27). In some terms, Amir al-Mu'minin (PBUH) has also established the appearance implication between two traits, of which the following examples can be cited: The relation between (Ao'sa'a andAzigh) in the phrase:

Fal haghgho aosa'o al-ashia fi al-tavasofe va azighoha fi-al-tanasofe Right in the description, is the most widespread phenomenon, and when you practice, the arena is tightest "(Sermon / 216).

And also between (al-Kabir, al-Saghir) in this speech:

Yahremo fiha al-kabir va yoshobo fiha al-saghir va yakdeho fiha momeno hatta yalgha rabbaho "He keeps the elderly worried, keeps the young old, and keeps worried the believer up to the resurrection and meeting the Lord" (Sermon/3).

The relationship between (Akhfaz and A'ala) in the following words: Konto akhfazohom satan va a'alahom faotan My voice was slower than ever, but in practice I was superior and pivotal (Sermon/37). In some cases, the appearance implicationhas been established between two words that are different in syntax, such as those found in the contradiction between the (Azhakni and Ebka) as verb and infinitive: Fa laghad azhekni al-kahro ba'ada ebkaehi The time after made me cried, caused me to laugh (Sermon / 162). Thus, can be said all samples of the appearance implication in the technical illustrations in Nahj-al-Balagha's political sermons are requirement one, and no example of deprivation implication.

\section{The hidden implication}

It was pointed out that hidden implication means that the contrast between the explicit appearance of a word and the necessity of another word, in this context we have examined the samples of this implication and found the following examples: Fal hoda khamelon va al omi shamelon "Guidance was sluggish and misleading was common"(Sermon / 2).

The texture of such a statement makes it necessary to establish an implication between the two sides of the words (Alhoda, Al-Ami), according to the same relation, which the meaning of Al-Ami is not physical blindness, but distraction and misleading. Thus Imam Ali (PBUH) has used this term (Al-Ami) instead of terms such as (al-tayah, al-zalala) to create between the two words (al-Hoda, al-Ami) a hidden implication. Hatta takoona nosraho ahadekom men ahadehem ka-nosrahe al-abde men sayyedeh, eza shhdaho ata'aho va eza ghaba aghtabah In such a way that you can help one another, like helping a slave from his master, who is obedient in the presence of the master and mumble in his absence "(Sermon / 98) (Sermon / 98).

In the final part of this word, we encounter two conditional terms, and the texture of the word requires that there be implication between two sentences. In relation to the conditional verb, it should be said that the existing implication (Dhahd/Ghab) is of appearance implication, and on this basis, naturally, there must also be an implication relationship between the two conditional clauses, if the purpose was the explicit contradiction forthe term (a'ta'a), theverb (asa'a) must be used, but Imam Ali (PBUH) used the verb (Aghtab), which is a means of revenge and defiance, to createhidden implication between these two 


\section{MUSICALITY IN POLITICAL SERMONS OF NAHJ AL-BALAGHA LITERARY REVIEW OF TECHNICAL IMAGES IN THE PRESENCE OF IMAM ALI (PEACE BE UPON HIM)}

answers and, in fact, between the two sentences. This is the explanation that backbite (Al-eghtiab) is a kind of inward insulting and hidden implication implicatesthe affair which backbite is about.

Another example of the use of hidden implication in the technical images of Nahj-al-Balagha's political sermons is as follows: Tafeghto artaei bayna osoola be-yaden jaza'a ao asber ala takhyaen amya'a I was wondering if I could stand alone with my hand to get my right, or wait in this dark, suffocative environment (sermon/3).

In this statement, between the two verbs (ossol and asber) we see the hidden implication. Imam Ali (PBUH) uses the letter (ao) which expresses the option between the two words, creating an implication and separating them from each other. Because the term (takheer) means that two or more objects can't be combined together"(Salman, 2003: 67). In this context, texture does not allow alsoola (rushing) and al-sabr (patience) to form together, but the implication between these two words isn't appearance one, as these words do not have apparent contradictions. It can be said that patience (sabr) is a matter of tolerance and enduranceis a matter of tolerance and peace even if it be reluctantly, and thus between the verbs of the (osool) and (al-sabr), which are instruments of peace and harmony, the hidden implication has been established.

These examples indicate the use of hidden implication in the presence of Imam Ali (PBUH), but certainly in most cases he has used the hidden implication between the two sentences, whereas the context of the word leads to a hidden implication in the sentences.

"The contradiction is one of the most prominent elements of the rhythmic structure of the words" (Abu Raghif, 2011: 75). And if the goal of rhetoric is to depict objects or deepen their understanding of them in the minds of the audience, in this mod, the implication is one of the solutions to this goal. Therefore, Imam Ali (PBUH), with the attention of the rule of "know the objects with their contradiction" has not overlooked the effective capacity of the implication in deepening the meaning and has used this rhetorical feature in the creation of spiritual music. The final point is that according to the review carried out in this article, it has to be said that spiritual music in technical pictures of Nahj-al-Balagha's political lectures (sermons) is only unique in terms of implication and does not include other features.

\section{Conclusion}

The result of the study is that Amir al-Mu'minin $(\mathrm{P}\{\mathrm{BUH})$ is fully familiar with the technical capacities of the letters, vows, words, sentences and phrases, and therefore in his political speeches that require the influence and persuasion of the audience and the soften the reasons and the hearts, has applied these capacities. One of the characteristics of the power of interpretation in presence of Imam is the strong music, which is included in the lectures in both its verbal and spiritual forms, and the technical images are mixed with a rhythm in order to influence the word in the audience, which is one of the dimensions of the genius of Amir al-Mu'minin (PBUH). As a matter of fact, Imam created a confection from all capacity of a technical image with an exquisite musical dimension and thus, it has created a word like a miracle. Of course, verbal imagery music has been used in all of its form in political sermons of Nahj-al-Balagha, but spiritual imagery music has been limited only in the circle of the implication with its two types of appearance and hidden, and the other types of spiritual music such as marriage and confrontation is not observed.

Another finding is that music in Nahj al-Balagha itself is not an independent purpose in itself, but serves the meaning and purpose and in line with it, while it can't be regarded as only a collection of recurrent vocals and melodies, but also this music focuses on the spatial sense of the word in order to establish a continuous link between the orator, the audience and the subject. Therefore, Aqqad has not gone wrong, where he claims that "Imam Ali (PBUH)" was the first person to consider literally the speech of the sermon "(See Aqqad, 1967: 181).

The end of the speech is that the technical picture in the Nahj-al-Balagha'apolitical sermons depicts rational, emotional, and musical combination in the moment of time in front of the audience that itself is created and the result of the harmony and alignment of its elements and the form's alliance with content, 


\section{MUSICALITY IN POLITICAL SERMONS OF NAHJ AL-BALAGHA LITERARY REVIEW OF TECHNICAL IMAGES IN THE PRESENCE OF IMAM ALI (PEACE BE UPON HIM)}

and thought with feelings. The style of the Imam teaches us that technical prose does not mean scattered material, but this prose emphasizes the phonetic order and musical chord, whose significance is in no way less than sound discipline in poetry, and thus music enters in the field of competition among the elements of the technical image and its features.

\section{References}

Abbas, H. (1998). Characteristics and meanings of Arabic letters. Publications of the Arab Book Union.

Abu Raghif, Noofal Hilal (2011). Aesthetic levels in the Nahj-al-Balagha ( $2^{\text {nd }}$ ed.). Baghdad: A series of new academics.

Abu Zahra, M.. (1943). the rhetoric, its origins and history in the flowering of its era among the Arabs. I. BJ: Science Press.

Al-Alawi, Y. bin H.bin Ali ibn Ibrahim. (1333 AH). Model. Egypt: Al-Muqtaf Printing Press.

Al-Askari, Abu Al-Hilal. (1320 AH). The two industries (1 ${ }^{\text {st }}$ ed.). Egypt: Mahmoud Beck Press.

Al-Atiq, Abdel Aziz. (1972). in literary criticism. I. Beirut: Arab Renaissance House.

Al-Fallah, Qahtan Saleh. (n.d.). Political rhetoric in the first Abbasid era. Journal of Arab Heritage. No. 106. pp. 203-181.

Al-Jarjani, Abdel-Qaher. (1991). Secrets of rhetoric. Cairo: Civil Press.

Al-Jarjani, Ali bin Abdul Aziz. (2006). Mediation between Mutanabi and his opponents. Investigation: Mohammad Abu Al-Fadl Ibrahim and Ali Mohammed Al-Bagawi. Beirut: Modern Library.

Al-Madani, Al-seyed. Ali Sadr Al-Din bin Maasoum. (1969). spring lights in the types of materials. Achievement: Shaker Hadi thanked. I. Najaf Al - Ashraf: Al - Nu'man Press.

Al-Qizayni, Saad al-Din Abu Muhammad Abdul Rahman. (n.d.). Explanation in the science of rhetoric. Beirut: Scientific Books House.

Al-Sawy Al-Jawini, Mustapha. (1985). Arab rhetoric and renewal. Alexandria: Dar Al Ma'arif Establishment.

Al-Zamakhshri, Abu al-QasimJarallah Mahmoud bin Omar bin Ahmed. (1998). Basis of rhetoric. Investigation: Mohammed Basil. $1^{\text {st }}$ edition. Beirut: Scientific Books House.

Al-zannad, Al-Azhar. (1992). Lessons in rhetoric ( $1^{\text {st }}$ ed.). Beirut: White House.

Aqqad, Abbas Mahmoud. (1967). The genius of Imam Ali. Beirut: Arabic Book House.

Aristotle, T. (1979). Public Speaking. Achievement and suspension: Abdul Rahman Badawi. Beirut: House of Pen. 


\section{MUSICALITY IN POLITICAL SERMONS OF NAHJ AL-BALAGHA LITERARY REVIEW OF TECHNICAL IMAGES IN THE PRESENCE OF IMAM ALI (PEACE BE UPON HIM)}

BehRagham, N. (2014). Musical Features of rhyme in Nahj al-Balagha. Quarterly of Nahj alBalaghaResearch, Second year, 6, 107.

Dakhil, M. H. (2001). Speak rhetoric approaches (1 ${ }^{\text {st }}$ ed.). Beirut: Dar al-Mortazi.

Faham, Abbas Ali. (2012). The Qur'anic effect in the rhetoric approach. Najaf Al Ashraf: The Holy Top Floor.

Fakhouri, H. (1986). The whole in the history of Arabic Literature Ancient literature ( $\left.1^{\text {st }} \mathrm{ed}.\right)$. Beirut: House of the Generation.

Hamedawi, Khalid K. H. (2011). Creative methods in the rhetoric approach. Supervisor: MashkourKadhim Al-Awadi. University of Kufa.

Hashemi, Ahmed. (1999). Jawahar al-Balaghah. Investigation: Mohamed El Tonji ( $1^{\text {st }}$ ed.). Beirut: Knowledge Foundation.

Ibn al-'Athir,'Abou al-Fatih Zia 'al-Din. (1939). Alamedelalsaire (Proverbs Stepper). Research: Mohammad MohiyeddinAbdolhamid. Egypt: Mustafa al-Babi publication.

Ibnabilhadid. (2007). A description of Nahj al-Balagha.Research: Mohammad Ibrahim. Baghdad: Dar-alKetab-al-arabi.

IbnManzoor. (n.d.). Arabic language (Lesan-al-arabi): Cairo: Dar-al-Moaref.

Jordac, George. (2002). Masterpieces of the approach of rhetoric. I. Beirut: Dar al-Ghadir.

Jordan: Dar Al Radwan. (2014). Eloquence approach in rhetoric approach ( $\left.1^{\text {st }} \mathrm{ed}.\right)$.

Khouli, M. A.(1982). Dictionary of sounds. I. Saudi Kingdom: Farazdak Printing Press.

Matloob, A. (1983). Dictionary of rhetorical terminology and its evolution. Iraq: Press of the Iraqi Science Academy.

Mobarak, Z. (2010). Artistic prose in the fourth century. Cairo: Egyptian General Book Authority.

Omri, H. (2010). Discourse in a rhetoric approach. I. Beirut: Scientific Books House.

Omri, M. (2002). In eloquence of the discourse of persuasion. Beirut: Forum of the Azabic Wall.

Ragheb, Abdel Salam Ahmed. (2001). The function of the artistic image in the Holy Qur'an ( $1^{\text {st }}$ ed.).

Aleppo: Dar Faslt.

SaadounHanoun, Hadi. (2012). Artistic photography in the sermons of Al-Hasira from Mecca to Medina. Najaf Al Ashraf: The Holy Top Floor.

Saleh, S. (2004). Approach (2 ${ }^{\text {nd }}$ ed.). Cairo: Egyptian Book House.

Salman, Ali Jassem. (2003). Encyclopedia of the meanings of letters. Amman: Dar Osama.

Shawi, Abdul Hadi Abdul Rahman Ali. (2007). The proverbs in the rhetoric approach are a technical study. Supervisor Professor: Khalil Abdul Sada Ibrahim. University of Kufa.

Sheikho, L. (1926). Art of literature. Third edition. Beirut: Press of the Jesuit Fathers. 


\section{MUSICALITY IN POLITICAL SERMONS OF NAHJ AL-BALAGHA LITERARY REVIEW OF TECHNICAL IMAGES IN THE PRESENCE OF IMAM ALI (PEACE BE UPON HIM)}

Sultan, M. (1986). Innovations and renewals. Alexandria: Knowledge Establishment.

Taftazani, Saad al-Din. (1428 BC). Explanation of the Manual. Holy Q: Ismaili Publications. The Holy Quran.

Contact details of the authors

Mohammad Saleh Sharif Askari,

Associate professor of Arabic Language and Literature, Kharazmi University, Tehran, Iran

Hamed Fashi, Corresponding Author

$\mathrm{PhD}$ student in Arabic language and literature, Kharazmi University, Tehran, Iran

Email: hamedfashi@yahoo.com 